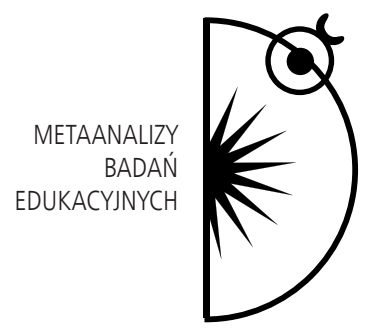

Krzysztof Rubacha

\title{
Standardy badań społecznych. Problematyzowanie praktyki edukacyjnej
}

DOI: http://dx.doi.org/10.12775/PBE.2013.004

\section{Wprowadzenie}

Użycie terminu „problematyzowanie” informuje, że ten tekst będzie dotyczył czynności, które prowadzą do sformułowania pytań i hipotez kierujących badaniem naukowym. Praktyka edukacyjna jako przedmiot badań stanowi przestrzeń, do której badacze „przymierzają” teorie, będące ostatecznie narzędziem problematyzacji i kryterium interpretowania wyników badania. Tak więc relacja między teorią a praktyką edukacyjną będzie przedmiotem pierwszej części artykułu. Ponieważ jednak użycie teorii zawsze wytycza granice wyjaśnienia, jakie przy ich użyciu możemy wygenerować, w drugiej części tekstu spojrzymy na problematyzowanie jako konstruowanie wyjaśnienia. By jednak to wyjaśnienie miało charakter naukowy, pytania i hipotezy badawcze muszą respektować zasadę konwencjonalności poznania naukowego. I o tym, jak badacze pracują, by tę zasadę zachować, będzie informowała trzecia część tego artykułu.

\section{Problematyzowanie jako konstruowanie podstaw teoretycznych badania}

Analizując relację między teorią i praktyką edukacyjną z punktu widzenia problematyzowania jako etapu procesu badawczego, musimy odwołać się do jednej z dwóch możliwych sytuacji. Obie łączą się z typem badania. Jeśli ba- 
danie planujemy jako teoretyczne - weryfikacyjne, teoria jest jego sednem, a praktyka pełni funkcję instrumentalną, tzn. jest przestrzenią (kryterium) do weryfikowania teorii. W takiej sytuacji to teoria, czy konkretne twierdzenie, jest przedmiotem wyjaśnienia, nie zaś fakt z praktyki edukacyjnej. Planując badanie weryfikacyjne, musimy szukać takiej formy praktyki edukacyjnej, która pozwoli zweryfikować twierdzenie teoretyczne. Inaczej postąpimy w pozostałych typach badań, a więc w badaniach teoretycznych - eksploracyjnych i praktycznych - diagnostycznych, oceniających i w działaniu. W każdym z tych przypadków sednem badania jest praktyka edukacyjna, a teoria stanowi kryterium problematyzacji. Praktykę zatem traktujemy jako przestrzeń faktów (danych) wymagających wyjaśnienia, teorię natomiast jako przestrzeń znaczeń, które poddamy wyjaśnieniu. Relacja między teorią i praktyką edukacyjną w interesującym nas kontekście jest różnie konceptualizowana, w zależności od strategii badań czy de facto od celu badań. Jeśli zmierzamy do ustalenia ogólnych prawidłowości, opisujących populację generalną, posługujemy się strategią ilościową. Ta zaś wymaga precyzyjnego zdefiniowania zmiennych, w ściśle określonym kontekście teoretycznym, który narzuca konkretne operacjonalizacje badanych zmiennych. Nie mierzymy „nagich” faktów, lecz konstrukty teoretyczne, które za pośrednictwem narzędzia zbierania danych, przekształcimy w konstrukty empiryczne. Te będą odwoływały się już do doświadczenia badanych obiektów (źródła danych), kanalizując je jednak zgodnie $\mathrm{z}$ definicjami wyjściowymi zmiennych. W przypadku strategii jakościowej problematyzowanie jest procesem definiowania zmiennych, konceptualizowania relacji między nimi na podstawie twierdzeń konkretnej teorii. Narzucony w ten sposób język danych (najczęściej behawioralny) będzie nie tylko językiem pomiaru, ale także językiem wyjaśnienia. Warto przy tej okazji podkreślić, że teoria stanowi perspektywę, z której przyglądamy się faktom i z której zadajemy pytania wobec rzeczywistości edukacyjnej, a więc także projektujemy oczekiwane wyjaśnienia. Tym właśnie różni się badanie naukowe od badania demograficznego, którego wyjaśnienia nie mają nadanych znaczeń teoretycznych.

Drugi przypadek relacji między teorią a praktyką edukacyjną ma miejsce, gdy celem badań jest wyjaśnienie indywidualizujące, ugruntowane w danych, a badanie jest organizowane w ramach strategii jakościowej. Sednem badania nadal jest praktyka edukacyjna. Teoria natomiast jest wprowadzana w trzech momentach, lecz nie towarzyszy badaniu w sposób ciągły. Pierwszy raz pojawia się, gdy badacz wstępnie zakreśla ramy pojęciowe badań. Próbuje nazwać przedmiot wyjaśnienia i zakreślić jego granice teoretyczne. Wtedy, posługując 
się teorią, patrzy na badaną rzeczywistość, by zbudować pytanie badawcze, nadające badaniu kierunek. Tak zakreślone ramy pojęciowe nie mają charakteru stałego, ponieważ badanie nie jest precyzyjnie zaplanowane, raczej „staje się" w trakcie kontaktów badacza z terenem. Docierające do badacza dane mogą modyfikować ramy teoretyczne: poszerzając je lub zawężając. Moment nawiązania przez badacza kontaktów z terenem jest właśnie drugą odsłoną teorii, ponieważ jest ona ukryta w metodzie zbierania i analizowania danych (np. wywiady w modelu F. Schützego). Typowe dla danej metody zachowanie się badacza wpływa na zbierane dane, nadając badaniu kolejny rys teoretyczny. Jednak znaczenie teorii w omawianym przypadku jest inne niż w strategii ilościowej. O ile tam badacz wie, do jakich danych dotrze (wcześniej przygotowane narzędzia: testy, kwestionariusze ankiet, arkusze obserwacji), o tyle w strategii jakościowej tego nie wie (wywiad, obserwacja uczestnicząca, przeszukiwanie źródeł). A to oznacza, że dane empiryczne, tak jak w przypadku ram pojęciowych, mogą nadal modyfikować teoretyczny kontekst badania, choć na tym etapie te możliwości ulegają ograniczeniu. Na pewno jednak pobyt badacza w terenie odsuwa na plan dalszy teorię, by powróciła po raz trzeci na etapie interpretacji uzyskanych wyjaśnień. Mowa oczywiście o nadawaniu znaczeń uzyskanym wynikom. Są to zatem momenty, w których teoria dominuje, pomiędzy którymi badacze starają się uwolnić od wszelkich nastawień w poznawaniu badanych obiektów. Starają się, choć nie jest to do końca możliwe, choćby za sprawą teorii ukrytej za metodami zbierania i analizowania danych. Nie jest też pożądane, ponieważ utrata dystansu wobec danych oraz kryterium nadawania im znaczeń nie poprawia jakości badania naukowego.

Repertuar teorii jako potencjalnych podstaw badań naukowych prezentuje paradygmaty badań społecznych, będące przesłankami wyjaśniania. Są to przesłanki ogólne, konstruowane na poziomie ontologicznym, epistemologicznym oraz metodologicznym. Na tych samych poziomach różnicują się strategie badań społecznych, a więc ilościowa i jakościowa. Przyjmując klasyfikację paradygmatów badań zaproponowaną przez R. Paulstona (Kwieciński 1993, s. 23), widzimy, że teorie, które mogą być używane do problematyzacji badań w strategii jakościowej, znajdują się w obrębie paradygmatów radykalnego humanizmu oraz interpretatywizmu. Strategie jakościowe natomiast są problematyzowane za pomocą teorii strukturalistycznych i funkcjonalistycznych. Innym układem przesłanek ogólnych jest klasyfikacja G. Burrella i G. Morgana (Burrell, Morgan 1979, s. 8-20) z paradygmatami interpretatywnym, krytycznym i normatywnym. Dwa pierwsze są idiograficzne, a ostatni nomotetyczny. Z przesłankami ogólnymi paradygmatów badań łączą się także schematy badań 
oferujące szczegółowe typy wyjaśnień, które są kolejną kategorią regulującą problematyzowanie praktyki edukacyjnej.

\section{Problematyzowanie jako konstruowanie wyjaśnienia}

W obrębie paradygmatów nomotetycznych dostępne są trzy typy wyjaśnień. Wyjaśnienia przyczynowo-skutkowe - ujawniające wpływ zmiennych na zmienne, korelacyjne - pozwalające oszacować współwystępowanie badanych praktyk edukacyjnych i quasi-eksperymentalne - szacujące różnice między populacjami w zakresie badanych praktyk edukacyjnych. W zasadzie problematyzowanie oznacza w tym przypadku zaplanowanie pożądanego wyjaśnienia przez ustalenie czynności typowych dla danego schematu badania. Jest to więc dość szczegółowa analiza pola badania, która musi się zmieścić w możliwościach, jakie daje teoria, z perspektywy której patrzymy na praktykę edukacyjną. Nie wszystkie teorie dysponują taką siatką pojęć i modeli zależności pomiędzy zmiennymi, która będzie otwarta na wszystkie wymienione wyjaśnienia. Zależy to w dużej mierze od schematów badań, na bazie których formułowano twierdzenia teoretyczne. Teorie uczenia się, teorie społeczno-poznawcze, neobehawioralne są zdecydowanie otwarte na wyjaśnienia przyczynowo-skutkowe, ponieważ większość badań w tych tradycjach przebiegała w schemacie eksperymentalnym. Nie jest tak jednak w przypadku teorii wyjaśniających zależności między cechami osobowości, które okazują się trafne w badaniach nad rezultatami procesów edukacyjnych. Sieć pojęć tych teorii najlepiej przysłuży się wyjaśnieniom współwystępowania i dotyczącym różnic pomiędzy populacjami uczniów, ponieważ „czystość teoretyczna” badania jest ukryta w adekwatnym doborze teorii wyjściowej do oczekiwanego typu wyjaśnienia. Zresztą problematyzowanie to także takie przyglądanie się praktyce edukacyjnej, które powinno ogniskować trafną diagnozę pożądanego wyjaśnienia (jakie wyjaśnienie jest potrzebne, by poznać wybrany fragment praktyki edukacyjnej) oraz trafny dobór teorii, która będzie niesprzeczna z tym wyjaśnieniem.

W obrębie paradygmatów idiograficznych dostępne są z kolei wyjaśnienia dotyczące indywidualnego (swoistego) przebiegu zjawiska ogólnego (studium przypadku), genetyczne (schemat badań historycznych) oraz reguł funkcjonowania kultury (schemat etnograficzny). Teorie używane w strategii jakościowej nie mają tak silnego, jak w ilościowej, związku z typami wyjaśnień, zwłaszcza gdy myślimy o teoriach, z perspektywy których formułujemy ramy pojęciowe badań. Nieco inaczej jest już w przypadku teorii ukrytych za metodami zbierania i analizowania danych. Niektóre z nich bowiem są dość wąskie, a ich in- 
strumentarium nie pozwala na dojście do każdego typu wyjaśnienia. Dobrym przykładem będzie tu - wspominana już wcześniej - teoria struktur procesowych F. Schützego, która nie jest elastyczna w odniesieniu do każdego rodzaju wyjaśnienia odkrywającego reguły funkcjonowania kultury, czy genetycznego. Wydaje się natomiast bardzo dobra do wyjaśnień typowych dla studium przypadku. Nie można więc powiedzieć, że problematyzowanie w strategii jakościowej w zdecydowanie mniejszym stopniu niż w strategii ilościowej ingeruje w relacje między teorią i wyjaśnianiem. Nie jest to w każdym razie różnica jakościowa, raczej ilościowa różnica stopnia.

Dotychczas opisujemy standardy prostych problematyzacji, odniesionych do jednej tylko strategii badań. Praktyka edukacyjna jednak toczy się spontanicznie, zarówno na poziomie ogólnych prawidłowości, jak i indywidualnych, swoistych przypadków. Co więcej, te procesy przeplatają się i - najprawdopodobniej - wzajemnie warunkują. Może świadczyć o tym fakt, że prowadząc badanie korelacyjne, odkrywamy prawidłowość, od której zawsze są wyjątki, co widać po wysokości współczynnika korelacji. Niekiedy łatwo jest policzyć, ile przypadków z badanej próbki nie spełnia ustalonej prawidłowości. A przecież są to często badani z tej samej populacji, poddani tym samym, uważanym za „obiektywne”, oddziaływaniom. Zwykło się wtedy mówić: wyjątki potwierdzają regułę. Jest to jednak obronna sentencja, wynikająca z bezradności metodologicznej. Z tego powodu warto zastanawiać się nad bardziej złożonymi problematyzacjami, które są projektowane, by całościowo wyjaśnić badane zjawiska. Jeśli w pierwszym kroku problematyzujemy praktykę edukacyjną do postaci wyjaśnienia przyczynowo-skutkowego i wiemy, że w społeczeństwie (w populacji) nie ma idealnych zależności, możemy od razu tę problematyzację rozszerzyć na wyjaśnienie typowe, np. dla studium przypadku. Problem zgodności dwóch typów wyjaśnień, można częściowo rozwiązać, planując takie analizy danych, które w strategii jakościowej weryfikują zależności przyczynowo-skutkowe (por. Miles, Huberman 2000), będące przedmiotem wyjaśniania w pierwszej części badań. Można też tak problematyzować praktykę edukacyjną, by strategii jakościowych używać jako kryteriów weryfikacji danych zebranych przy pomocy strategii ilościowej lub odwrotnie. Gdyby natomiast nie łączyć obu strategii w jednej problematyzacji, uzyskane wyjaśnienie można potraktować jako punkt wyjścia do nowej problematyzacji (niezależnej), która nie musi już respektować reguł zgodności metodologicznej. Będzie po prostu badaniem wyjaśniającym inny kontekst, aspekt badanego zjawiska. Każda bowiem problematyzacja prowadzi do oświetlenia konkretnego fragmentu praktyki edukacyjnej i w sensie poznawczym jest tyle warta co inne, jeśli jest tylko poprawna. 


\section{Problematyzowanie jako formułowanie pytań i hipotez badawczych}

Doszliśmy w ten sposób do konwencjonalnego charakteru poznania naukowego. Każda bowiem problematyzacja jest redukcją praktyki edukacyjnej do konkretnej postaci o wyraźnym rodowodzie teoretycznym, który ostatecznie jest źródłem nadawania znaczeń uzyskanym wynikom badania. Nie poznajemy więc praktyki edukacyjnej w sensie uniwersalnym, lecz jej wyjaśnienia w obrębie jakiegoś systemu teoretycznego. Konsekwencje tego stanu rzeczy towarzyszą także ostatniej fazie problematyzacji, czyli formułowaniu pytań i hipotez badawczych. Standard problematyzacji polega więc na jej ulokowaniu w operacjonalizacji zmiennych. Oznacza to, że pytania i hipotezy badawcze nie mogą być formułowane w kategoriach ogólnych, lecz w odniesieniu do konkretnego typu wyjaśnienia, jakie jest celem badania oraz do konkretnie zdefiniowanych zmiennych. Nigdy bowiem nie badamy samooceny uczniów bez odniesienia do teoretycznego kontekstu, lecz samoocenę w konkretnej konwencji teoretycznej, która jest czymś innym niż samoocena w innej konwencji teoretycznej. Nigdy też nie sprawdzamy relacji między zmiennymi w sensie ogólnym, lecz konkretne relacje, których desygnaty są zapisane w sproblematyzowanym typie wyjaśnienia. Aby zatem konsekwentnie problematyzację doprowadzić do końca, trzeba pytania i hipotezy przedstawić w postaci zoperacjonalizowanej. Zacznijmy od hipotez. Formułujemy je w badaniach teoretycznych - weryfikacyjnych. Hipoteza jest wtedy logicznym wnioskiem z twierdzenia teoretycznego, odniesionym do warunków empirycznych, które pozwolą ją zweryfikować (Konarzewski 2000, Rubacha 2008). Pierwsza kwestia łączy się zatem z poprawnością metodologiczną hipotezy. Musi być tak sformułowana, by zawierała warunki, w których prawdopodobieństwo jej odrzucenia będzie takie samo jak prawdopodobieństwo jej przyjęcia. To podstawowy standard. Druga kwestia łączy się z typem wyjaśnienia, który pozwoli na weryfikację hipotezy. Obie kwestie sprawiają, że w hipotezie trzeba zawrzeć szczegółowe warunki jej weryfikacji. Nie może być więc hipoteza jednym zdaniem typu: „zachodzą zależności miedzy badanymi zmiennymi”. Taki jej sens nie wynika bowiem w żaden sposób z wcześniejszych czynności badacza problematyzującego pole swoich badań. Takie zdanie ponadto jest fałszywą informacją, obietnicą bez pokrycia, że badacz zdoła ten związek miedzy zmiennymi wyjaśnić uniwersalnie. Zgodnie zatem z omawianym standardem metodologicznym, hipoteza musi zwierać weryfikowane twierdzenie teoretyczne oraz warunki jego weryfikacji, czyli dokładny opis procedury badania wraz z nazwami zmiennych, z odniesieniem 
ich do narzędzi badawczych i do typu wyjaśnienia, które zawiera uprzednio zaplanowana problematyzacja. Hipoteza zatem jest opisem warunków, w których trafność twierdzenia zostanie potwierdzona lub niepotwierdzona. Zdanie: ,jeśli twierdzenie o wpływie nastawienia na spostrzeganie jest prawdziwe, to osoby badane z grupy A, które były poddane manipulacji badacza, polegającej na podpowiadaniu im fałszywych rozwiązań zadania, uzyskają wyższą średnią błędów w wygenerowanych rozwiązaniach niż osoby z grupy B, która nie była poddana tej manipulacji" - spełnia wyżej sformułowane warunki. Warto zauważyć, że hipoteza ta pokazuje zakres wyjaśnienia - nie jest to absolutne, uniwersalne wyjaśnienie relacji między nastawieniem a spostrzeganiem, lecz odniesione do tego, co w rzeczywistości badano. Jest to odniesienie do konwencji, w której dokonano problematyzacji. Tak sformułowana hipoteza pozwala zresztą zrekonstruować cały proces problematyzacji badania. I to ostatnie jest testem jej poprawności. Podobnie rzecz wygląda w przypadku pytań badawczych. Możemy pytać jedynie o taki zakres relacji między zmiennymi, który zostanie w badaniu zweryfikowany. Analogicznie możemy pytać o zmienne tak rozumiane, jak wynika to $\mathrm{z}$ ich definicji. Warto pamiętać, że np. motywacja może być stanem niezaspokojenia potrzeb (Maslow 1990), ale może też być różnicą między nasileniem dążenia do sukcesu i lęku przed porażką (Atkinson za: Madsen 1980). Czy zatem ktoś może zbadać motywację w ogóle? Tych definicji jest jeszcze kilkanaście. I wreszcie możemy pytać o konkretne wyniki osób badanych, które uzyskaliśmy przy użyciu konkretnych narzędzi pomiaru, nie zaś o jakieś wyniki. To wszystko oznacza, że jeśli problematyzacja w postaci pytania badawczego ma wynikać ze swoich uprzednich etapów, pytanie musi zawierać takie nazwy zmiennych, jakie są teorii wyjściowej, musi odwoływać się do zastosowanych narzędzi badania oraz musi precyzyjnie nazywać typ wyjaśnienia, do którego badanie zmierza. Pytanie badawcze: ,jakie są różnice w średnich wynikach samooceny cząstkowej mierzonej testem X pomiędzy badanymi, którzy wyrazili akceptację i nie wyrazili akceptacji dla szkolnego systemu ocenia?" - spełnia wyżej opisane warunki. Można też za pomocą jego analizy zrekonstruować typ wyjaśniania oraz teorię leżącą u podstaw tego badania, czyli wcześniejsze etapy problematyzacji. Spełnienie tych standardów sprawia, że problematyzacja zostaje poprawnie zakończona i pokazuje, że spełnia warunek konwencjonalności poznania naukowego. 


\section{Zakończenie}

Łatwo zauważyć, że omówione pojęcie problematyzacji (problematyzowania) mieści w sobie dwa procesy: konceptualizację (definiowanie zmiennych) oraz operacjonalizację (przekładanie języka teoretycznego na empiryczny). Jeśli tak, to problematyzacja stanowi lwią część procesu badawczego. Nawet jeśli, w innej konwencji, oddzielimy konceptualizację i operacjonalizację od problematyzacji, to i tak nie unikniemy złożonego procesu formułowania pytań i hipotez badawczych. To oznacza, że rozpoczynając problematyzację (definiowanie zmiennych), powinniśmy już widzieć nie tylko pomiar zmiennych, ale także metodę analizy wyników, bo to ona właśnie ostatecznie doprowadza do końca wyjaśnienie. Nie warto więc liniowo trzymać się sztucznie wyodrębnionych faz procesu badawczego. To raczej zataczanie wielu kół i to w obu strategiach badawczych.

\section{Bibliografia}

Ajdukiewicz K. (1985), Język i poznanie, t. 2, PWN, Warszawa.

Atkinson P., Coffey A., Delamont S., Lofland J., Lofland L. (eds.) (2001), Handbook of Ethnography, SAGE, London.

Burrell G., Morgan G. (1974), Socjological paradigms and organizational analysis, Heinemann, London.

Cohen L., Manion L., Morrison K. (2005), Research Methods in Education, RoutledgeFalmer, London-New York.

Denzin H. K., Lincoln Y. S. (eds.) (1994), Handbook of Qualitative Research, Sage, Thousand Oak, http://dx.doi.org/10.2307/2075820.

Feyerabend P. K. (1979), Jak być dobrym empirysta?, PWN, Warszawa.

Hammersley M., Atkinson P. (2000), Metody badań terenowych, Wydawnictwo Zysk i S-ka, Poznań.

Jałmużna T., Michalska I., Michalski G. (red.) (2004), Konteksty i metody w badaniach historyczno-pedagogicznych, Impuls, Kraków.

Kmita J. (1973), Wyktady z logiki i metodologii nauk, PWN, Warszawa.

Kmita J. (1976), Szkice z teorii poznania naukowego, PWN, Warszawa.

Konarzewski K. (2000), Jak uprawiać badania oświatowe. Metodologia praktyczna, WSiP, Warszawa. 
Kwieciński Z. (1993), Mimikra czy sternik? Dylemat pedagogiki w sytuacji przesilenia formacyjnego, w: Z. Kwieciński, L. Witkowski (red.), Spory o edukację. Dylematy i kontrowersje we wspótczesnych pedagogiach, Wydawnictwo „Edytor”, Warszawa.

Kuhn T. S. (1968), Struktura rewolucji naukowych, przeł. S. Amsterdamski, PWN, Warszawa.

Kuhn T. S. (1985), Dwa bieguny. Tradycja i nowatorstwo w badaniach naukowych, PIW, Warszawa.

Maslow A. (1990), Motywacja i osobowość, PIW, Warszawa.

Madsen K. B. (1980), Wspótczesne teorie motywacji, PWN, Warszawa.

Miles M. B., Huberman A. M. (2000), Analiza danych jakościowych, Transhumana, Białystok.

Pawłowski T. (1986), Tworzenie pojęć i definiowanie w naukach humanistycznych, PWN, Warszawa.

Rubacha K. (2008), Metodologia badań nad edukacją, WAiP, Warszawa.

\section{Standards of the social researches.}

Problematization of the education practice

\section{Summary}

The article is an analysis of the methodological standards of the problematization in the social and educational researches. This subject was describe through the three analytical category: conceptualization, explanation and the construction of the hypothesis and the research problems. 